\title{
A Comparative Analysis on Human Capital and Wage Structure in the Spanish Hospitality Sector
}

\author{
Juan A. Campos-Soria, A. García-Pozo, José Luis Sánchez-Ollero, Carlos G. Benavides-Chicón
}

Faculty of Economics and Business Studies, University of Malaga, Malaga, Spain.

E-mail: jlsanchez@uma.es

Received July $26^{\text {th }}, 2011$; revised September $10^{\text {th }}, 2011$; accepted October $15^{\text {th }}, 2011$.

\begin{abstract}
This paper presents a comparative analysis of the wage structures in the Spanish hospitality sector and other private service industries. Using data from the 2006 Spanish Wage Structure Survey (Encuesta de Estructura Salarial) [1], we estimate human capital returns in the hospitality industries. These results have been compared to those obtained in other private services. Education returns in these estimations are lower in the hospitality sector although there are significant differences between regions. Similar results were found for the other human capital variables used. Finally, the paper provides new empirical evidence on the regional wage gap in this sector. The main wage gap in the Canary Islands and the Madrid region is due to differences in returns in the observed variables, whereas in other regions most of the differences are due to the resources allocated.
\end{abstract}

Keywords: Human Capital, Tourism, Wage Differentials, Regional Analysis

\section{Introduction}

Tourism has been a determinant factor in the modernization of the Spanish economy. However, many aspects of this sector, such as labor market characteristics and regional differences, have not been widely studied. Tourism is a cross-sectional industry in which highly diverse activities are grouped. This paper analyzes the hospitality subsector which itself is composed of large and welldifferentiated subcategories ${ }^{1}$. In Spain, the hospitality industry is characterized by having a higher percentage of women and younger workers, lower educational levels, seasonality in contracts, a smaller percentage of employyees, a greater percentage of foreign workers, and higher than average working hours. However, regional differences are highly significant and the more precarious employment conditions tend to disappear in the more consolidated tourist destinations [2].

In this context, we estimate human capital returns and quantify wage differences for tourism regions in Spain. We also analyze whether wage differences at the regional level may be accounted for by differences in returns and observable characteristics. The estimations were performed using Oaxaca-Ramson wage estimations [3].

The paper is structured as follows: the methodology is

${ }^{1}$ Hotels, campsites and other types of accommodation; restaurants, bars, pubs and similar establishments; corporate dining rooms and catering. described in Section 2 and the variables that are included in the wage equations. The next two sections outline the database and present a descriptive analysis of the main variables (Section 3). Empirical results are detailed in Section 4. Finally, a brief description of the evidence obtained is provided and the main conclusions are formulated.

\section{Methodology}

\subsection{Theoretical Model and Econometric Specification}

The wage decomposition proposed by Oaxaca [4] and Blinder [5] has been used widely in the field to study discrimination in the labor market. We have based on it to quantify the proportion of regional wage differences due to differences in observable characteristics and the proportion due to the return differences derived from such characteristics. An appropriate estimation of the relationship between wages and different characteristics observed between regions, such as human capital, assists in interpreting important issues such as levels of regional inequality and mobility incentives between regions [6].

Under the assumption that observable characteristics in each region yield different returns, a wage equation has to be estimated for each region. Taking a Mincer wage equation as the starting point, Oaxaca and Ramson [3] pro- 
pose a generalization of Oaxaca-Blinder's decomposition in order to assume a more flexible wage structure in the absence of discrimination. The decomposition proposed in [3] is as follows:

$$
\ln \left(\bar{w}_{j}\right)-\ln \left(\bar{w}_{k}\right)=\left(\bar{x}_{j}^{\prime}-{\overline{x^{\prime}}}_{k}\right) \beta^{*}+\bar{x}_{j}^{\prime}\left(\hat{\beta}_{j}-\beta^{*}\right)+{\overline{x^{\prime}}}_{k}\left(\beta^{*}-\hat{\beta}_{k}\right)
$$

where $\ln \left(\bar{w}_{j}\right)$ and $\ln \left(\bar{w}_{k}\right)$ are the geometric means of the logarithm of the wage in region $\mathrm{j}$ and $\mathrm{k}$, respecttively; $\bar{x}_{j}^{\prime}$ and $\bar{x}_{k}^{\prime}$ are vectors for the geometric means of the observable characteristics for each region; and $\hat{\beta}_{j}$ and $\hat{\beta}_{k}$ are the vectors of the coefficients estimated for each region separately, i.e. the estimated returns for observable characteristics. Finally, the non-discriminatory wage structure can be understood as the returns of observable characteristics in competitive markets. If this matches region $\mathrm{j}$, then $\beta^{*}=\hat{\beta}_{j}$; if it matches region $\mathrm{k}$, then $\beta^{*}=\hat{\beta}_{k}$. Any combination of wage structures in the regions can also be considered as a non-discriminatory wage structure, in which case $\beta^{*}=\Omega \hat{\beta}_{j}+(I-\Omega) \hat{\beta}_{k}$, where $\Omega$ is the weighing matrix of such wage structures.

We assume two wage structures in the absence of discrimination. The first corresponds to the Balearic Islands $\left(\beta^{*}=\hat{\beta}_{\text {Balearic }}\right)$. This region was chosen as the reference because of the large differences compared to other regions specialized in "sun and beach" tourism, and the relatively high weight of hospitality employment in the total volume in the region. The second wage structure is based on a weighted mean of the wage structures of the six regions under analysis. The weights used in this case are the relative weights each region has on the total number of working people in the hospitality sector in the six regions ${ }^{2}, \Omega_{k}$; that is,

$$
\beta^{*}=\sum_{n=1}^{6} \Omega_{n} \hat{\beta}_{n}
$$

where " $n$ " represents each of the regions. The use of different $\beta^{*}$ makes it possible to provide the non-discriminatory wage structure taken as reference with more robust results.

\subsection{Descriptions of the Variables}

The wage equation estimated for each region has the following functional form (for reasons of simplicity subscripts for individuals are omitted)

$$
\begin{aligned}
\log (w r)= & \beta_{0}+\beta_{1} S+\beta_{2} \operatorname{Exp}+\beta_{3} \text { Ten }+\beta_{4} \text { Gender } \\
& +\beta_{5} \text { FTC }+\beta_{6} \text { SW }+\beta_{7} \text { Over }+\beta_{8} \text { Under }+\varepsilon
\end{aligned}
$$

${ }^{2}$ In a study on gender wage differences, [7] uses the weighted mean of men and women's wage structure. Namely, $\Omega=1_{h} \cdot I$, where $1_{h}$ is the proportion of men in the sample.
The dependent variable is the gross real wage per hour $^{3}$ expressed as logarithms. However, in order to isolate the effect of price differentials between regions, the level of regional relative prices were estimated to obtain the real wage/hour, i.e., the wage discounting the price differential in 2006 in each of the regions studied. Observations of workers with a wage lower than the interprofessional minimum wage and those younger than 16 or older than 65 years were eliminated from the original sample. The right-hand side of equation (2), includes the constant as well as the characteristics of the workers and jobs. Human capital variables, such as mean schooling years $(S)$, previous experience $(E x p)^{4}$ and tenure in the firm (Ten), and the gender of the employee (Gender) are derived from the characteristics of workers. Human capital variables were constructed following the work of $[8]^{5}$. Gender is a dummy variable that takes value 1 if the individual is a woman and 0 otherwise. This variable attempts to measure the different wage levels between men and women. Given the reduced size of the database for some regions, no iterations were done between gender and human capital variables to avoid problems of multicollinearity

In order to control the characteristics of the job we used the dummy variables type of contract, size of the establishment, and the formal education of the worker in relation to the job requirements.

The variable full-time and permanent contract (FTC) takes value 1 when the worker has a full-time permanent contract and zero in any other case. In this way, we attempted to assess whether this type of contract involves higher wages than to workers with temporary or parttime contracts. Both types of contract are aggregated into a single variable because in Spain they tend to be used together in the hospitality sector to help employers adjust the work supply to fluctuations in service demand.

The variable firm size $(S W)$, takes value 1 when the worker is employed in a firm with 20 or more employees, and zero in any other case. In Spain, the mean firm size in 2007 was 12.5 workers in hotel, and 3.9 in restaurants [10]. This shows the great variability observed between the two main hospitality subsectors in Spain. Thus, and taking into account the availability of statistical data at a

\footnotetext{
${ }^{3}$ This variable is calculated with the data available in EES-2006. The hours annually worked and the annual gross nominal wage received for the job are used in the calculations. It is also assumed that both 4.2 weeks and 30.42 days are equivalent to one month. Using the indexes of relative prices by Autonomous Communities in [9], the real wage for the year 2006 was obtained.

${ }^{4}$ This definition of potential previous experience (Expe $r=$ age-years of schooling - 6 years - tenure in the firm) is generally closer to actual previous experience in men and is likely to be overestimated in women due to leaving and entering the labor market to raise children.

${ }^{5}$ Observations of workers whose declared mean schooling years were clearly atypical are not included.
} 
regional level, business size has been taken as an additional explanatory variable of regional wage differences to control for the higher number of hotels in some tourist destinations. Furthermore, economic theory suggests alternative explanations to the fact that until a certain size is reached, wages increase with firm size (see [11]).

The variables Over and Under measure the fact that the real wage per hour could be more influenced by the type of job than by having a higher educational level. Although the database used controls for the type of job, there is a high correlation between educational level and occupation, and this creates high multicollinearity. Thus, following [12], occupation is taken into account indirectly by calculating a mean of the most frequent level of studies in each occupation. The mode is used as the statistical measure. However, this procedure is expanded in cases where the mode represents a percentage lower than $40 \%$ of the total number of employees in each occupation, defined at the level of two digits according to the National Classification of Occupations -CNO94- [13]. In these cases, the workers considered as appropriately educated are those who have obtained an educational level corresponding to the mode as well as those who have reached an adjacent educational level (immediately lower or higher). Thus, for a given occupation, if the mean number of study years required are 15 (undergraduates) but the mode includes a reduced number of cases (less than $40 \%$ ), workers with secondary education (12 study years) or postgraduates (17 study years) would be also considered appropriately educated. Choosing the level of studies immediately lower or higher than the mode was done by taking into account which level has a greater percentage of workers in each occupation.

Using this definition of appropriately educated workers, the dummy variables for the workers with a level of studies different from the one required by the occupation are defined as follows. The variable that represents overeducation (Over) takes value 1 if the worker has attained an educational level higher than the mode of each occupation (or the higher when two adjacent educational levels are possible); and zero in any other case. Similarly, the variable undereducation (Under) takes value 1 if the worker has an educational level lower than the mode of the occupation (or the lower when two contiguous educational levels are used); it will take value zero in any other case.

Finally, $\varepsilon$ is a random disturbance term.

\section{Database and Descriptive Analysis}

The information used was taken from the Spanish Survey of Wage Structure 2006 (Encuesta de Estructura Salarial, EES-2006). The sample is representative at the regional level (NUTS II), thus facilitating the present study.

Table 1 shows that workers in the Balearic Islands are older and have higher tenure in the firm. Furthermore, $64 \%$ of them have a full-time and permanent contract; this percentage is only exceeded by the Canary Islands (65\%). Other labor characteristics of this region include lower percentages of women $(47 \%)$ and higher nominal gross wages per hour. For these reasons, the Balearic Islands have been taken as the reference region for wage differrentials.

In the hospitality sector, mean schooling years is much lower than in other private service sectors. It should be pointed out that the Balearic and Canary Islands, which are mature destinations for sun and beach tourism [14], present the lowest mean schooling years of all the regions under consideration. This is probably due to the older mean age of workers who belong to the generation that did not benefit from the current Spanish educational system. In fact, this may account for the high proportion of undereducated workers (higher than $30 \%$ in both regions). We analyze this phenomenon later in this paper.

With the exception of the Balearic Islands, tenure is lower in the hospitality sector than in other private service industries. This suggests greater worker rotation in this sector, as reported in other studies [15]. Except for the Balearic and Canary Islands, 50\% of employees are women.

The percentage of workers suitably educated for their job fluctuates between the highest in Valencia (67\%) and the minimum in the Balearic Islands (51\%). These results do not substantially differ from the estimations obtained by [12] using a different database for the Spanish economy as a whole; and are also consistent with [16] for the hospitality sector in Andalusia. The percentage of overeducated workers ranges between $12 \%$ in the Canary Islands and 22\% in Madrid. The highest level of undereducation is found in both Spanish archipelagos and the lowest is found in Catalonia (15\%) and the Community of Valencia (16\%).

Table 1 shows that the rate per hour received in the hospitality sector is lower than the one received in other private service sectors. In nominal terms, the wage received by employees in the other regions as a whole is almost $19 \%$ less than in the Balearic Islands. In real terms, this difference decreases to $14.5 \%$ due to the differrential in relative prices. The greatest difference is found in Madrid where wages in the hospitality sector employyees are $40.1 \%$ lower.

\section{Empirical Results}

\subsection{Estimations}

Table 2 shows the results of the estimations in the hospitality sector and in other private service industries. The value of the constant term indicates the part of the wage 
Table 1. Characteristics observed in the sample of the chosen regions for the hospitality sector.

\begin{tabular}{|c|c|c|c|c|c|c|c|c|c|c|c|c|c|c|c|c|}
\hline \multirow[b]{2}{*}{ Variables } & \multicolumn{2}{|c|}{ Andalusia } & \multicolumn{2}{|c|}{ Balearic Island } & \multicolumn{2}{|c|}{ Canary Island } & \multicolumn{2}{|c|}{ Catalonia } & \multicolumn{2}{|c|}{ Com. Valencia } & \multicolumn{2}{|c|}{ Com. Madrid } & \multicolumn{2}{|c|}{ Other regions } & \multicolumn{2}{|c|}{ Spain } \\
\hline & $\mathrm{H}$ & OS & $\mathrm{H}$ & OS & $\mathrm{H}$ & OS & $\mathrm{H}$ & OS & $\mathrm{H}$ & OS & $\mathrm{H}$ & OS & $\mathrm{H}$ & OS & $\mathrm{H}$ & OS \\
\hline \multirow{2}{*}{ Age } & 35.02 & 36.84 & 40.58 & 37.98 & 39.17 & 36.86 & 36.72 & 38.09 & 36.65 & 37.85 & 38.52 & 37.69 & 36.34 & 39.39 & 37.26 & 38.32 \\
\hline & (10.93) & (10.13) & (11.60) & (11.30) & (10.53) & $(10.21)$ & (11.06) & (11.00) & (10.93) & (10.81) & (11.31) & (10.59) & (11.01) & $(10.70)$ & (11.13) & (10.72) \\
\hline \multirow{2}{*}{$\mathrm{S}$} & 7.63 & 10.54 & 6.89 & 10.05 & 6.74 & 9.46 & 8.07 & 10.80 & 7.41 & 10.03 & 7.81 & 11.59 & 7.56 & 10.58 & 7.50 & 10.71 \\
\hline & (3.77) & (4.59) & $(3.96)$ & $(4.73)$ & $(3.96)$ & (4.57) & (3.39) & $(4.35)$ & (3.66) & (4.58) & $(3.81)$ & $(4.53)$ & $(3.58)$ & (4.48) & $(3.70)$ & (4.53) \\
\hline \multirow{2}{*}{ Exp } & 14.59 & 12.14 & 17.06 & 13.76 & 18.77 & 13.65 & 16.40 & 13.15 & 17.76 & 13.84 & 17.15 & 12.35 & 16.42 & 13.64 & 16.76 & 13.17 \\
\hline & $(9.78)$ & $(9.41)$ & $(10.80)$ & (10.59) & (10.10) & $(9.62)$ & (10.40) & $(10.60)$ & (10.67) & (10.54) & (10.53) & $(9.82)$ & (10.52) & (10.17) & (10.49) & (10.14) \\
\hline \multirow{2}{*}{ Ten } & 4.52 & 7.00 & 7.74 & 6.70 & 4.62 & 6.13 & 4.40 & 7.19 & 4.00 & 6.61 & 5.34 & 6.92 & 4.08 & 8.05 & 4.63 & 7.35 \\
\hline & (6.99) & (8.69) & $(9.62)$ & $(8.08)$ & (6.93) & (7.79) & (6.67) & (8.74) & (6.57) & (8.68) & (7.07) & $(8.47)$ & (6.18) & $(9.44)$ & $(6.92)$ & $(8.92)$ \\
\hline \multirow{2}{*}{ Gender } & 0.52 & 0.54 & 0.47 & 0.64 & 0.49 & 0.58 & 0.55 & 0.62 & 0.56 & 0.55 & 0.65 & 0.58 & 0.62 & 0.58 & 0.58 & 0.58 \\
\hline & $(0.50)$ & $(0.50)$ & $(0.50)$ & $(0.48)$ & $(0.50)$ & $(0.49)$ & $(0.50)$ & $(0.48)$ & $(0.50)$ & $(0.50)$ & $(0.48)$ & $(0.49)$ & $(0.48)$ & $(0.49)$ & $(0.49)$ & $(0.49)$ \\
\hline \multirow{2}{*}{ FTC } & 0.50 & 0.56 & 0.64 & 0.54 & 0.65 & 0.60 & 0.49 & 0.57 & 0.48 & 0.54 & 0.52 & 0.61 & 0.56 & 0.56 & 0.55 & 0.57 \\
\hline & $(0.50)$ & $(0.50)$ & $(0.48)$ & $(0.50)$ & $(0.48)$ & $(0.49)$ & $(0.50)$ & $(0.50)$ & $(0.50)$ & $(0.50)$ & $(0.50)$ & $(0.49)$ & $(0.50)$ & $(0.50)$ & $(0.50)$ & $(0.50)$ \\
\hline \multirow{2}{*}{ SW } & 0.81 & 0.81 & 0.79 & 0.68 & 0.79 & 0.76 & 0.76 & 0.84 & 0.75 & 0.77 & 0.77 & 0.90 & 0.52 & 0.70 & 0.67 & 0.78 \\
\hline & $(0.40)$ & $(0.39)$ & $(0.41)$ & $(0.47)$ & $(0.41)$ & $(0.42)$ & $(0.43)$ & $(0.37)$ & $(0.44)$ & $(0.42)$ & $(0.42)$ & $(0.30)$ & $(0.50)$ & $(0.46)$ & $(0.47)$ & $(0.41)$ \\
\hline \multirow{2}{*}{ Over } & 0.20 & 0.22 & 0.15 & 0.14 & 0.12 & 0.16 & 0.20 & 0.18 & 0.17 & 0.16 & 0.22 & 0.20 & 0.19 & 0.18 & 0.18 & 0.19 \\
\hline & $(0.40)$ & $(0.41)$ & $(0.36)$ & $(0.35)$ & $(0.33)$ & $(0.37)$ & $(0.40)$ & $(0.39)$ & $(0.37)$ & $(0.36)$ & $(0.42)$ & $(0.40)$ & $(0.39)$ & $(0.39)$ & $(0.39)$ & $(0.39)$ \\
\hline \multirow{2}{*}{ Under } & 0.21 & 0.22 & 0.34 & 0.27 & 0.32 & 0.26 & 0.15 & 0.20 & 0.16 & 0.21 & 0.17 & 0.21 & 0.17 & 0.18 & 0.20 & 0.20 \\
\hline & $(0.41)$ & $(0.41)$ & $(0.47)$ & $(0.44)$ & $(0.47)$ & $(0.44)$ & $(0.36)$ & $(0.40)$ & $(0.37)$ & $(0.40)$ & $(0.38)$ & $(0.40)$ & $(0.38)$ & $(0.39)$ & $(0.40)$ & $(0.40)$ \\
\hline \multirow{2}{*}{$\begin{array}{c}\text { Nominal } \\
\text { wage }(€ / \text { hour })\end{array}$} & 8.66 & 12.51 & 10.09 & 12.07 & 8.90 & 10.87 & 9.98 & 13.52 & 9.04 & 11.64 & 8.62 & 14.59 & 8.17 & 12.65 & 8.84 & 13.00 \\
\hline & $(4.25)$ & $(9.94)$ & $(4.97)$ & $(8.41)$ & $(5.61)$ & $(8.28)$ & (5.59) & (9.99) & $(4.75)$ & $(7.64)$ & $(4.44)$ & (11.98) & $(3.35)$ & $(8.73)$ & $(4.43)$ & $(9.75)$ \\
\hline Price & \multicolumn{2}{|c|}{96.99} & \multicolumn{2}{|c|}{103.26} & \multicolumn{2}{|c|}{89.88} & \multicolumn{2}{|c|}{108.13} & \multicolumn{2}{|c|}{99.93} & \multicolumn{2}{|c|}{102.36} & \multicolumn{2}{|c|}{97.83} & \multicolumn{2}{|c|}{100.00} \\
\hline \multirow{2}{*}{$\begin{array}{c}\text { Real wage } \\
(€ / \text { hour })\end{array}$} & 8.93 & 12.90 & 9.77 & 11.69 & 9.91 & 12.10 & 9.23 & 12.50 & 9.05 & 11.64 & 8.43 & 14.25 & 8.35 & 12.93 & 8.84 & 13.00 \\
\hline & $(4.38)$ & $(10.25)$ & $(4.81)$ & (8.14) & $(6.25)$ & $(9.22)$ & $(5.17)$ & $(9.24)$ & (4.76) & $(7.65)$ & $(4.34)$ & (11.70) & $(3.38)$ & $(8.95)$ & $(4.43)$ & $(9.75)$ \\
\hline
\end{tabular}

Notes: Standard deviation values for the variables are shown in parentheses. Source: [1] and [9].

not affected by the independent variables. This component depends on other variables, such as lifestyle, climate and other differentiating characteristics of the regions that have an effect on the conditions of employment and wages, but which our specification was not able to include. The table shows that estimated values for the constant in the hospitality sector are greater than in the private sectors of services for all the regions. Furthermore, in the hospitality sector, as in the other private services, the maximum value of the constant term is found in the the maximum value of the constant term is found in the Community of Valencia and the lowest value in the Community of Madrid.

\subsubsection{Personal Characteristics}

Education returns in these estimations are lower in the hospitality sector. In addition, very significant regional differences are observed between the Canary Islands (5.5\%) and the Community of Valencia $(1.8 \%)$. In Catalonia
(4.8\%), the Balearic Islands (4.7\%) and Madrid (4.2\%), education returns are higher than the mean for Spain (3.2\%). These results reveal regional heterogeneity.

Our results are similar to previous studies that also use variables regarding job characteristics in their specification. Introducing these additional variables reduce educational returns, because these variables capture the indirect effect of education on wage and productivity. Accordingly, the education returns estimated in this work represent the direct effect of education, once the effects derived from the job characteristics are discounted.

The results of previous studies that specified the original Mincer equation showed education returns to be between $4.1 \%$ [17] when the estimation method used is ordinary least square and 5.6\% [18] when instrumental variable techniques are used. Nevertheless, in both papers, education returns in the hospitality sector are less than the estimates for most economic sectors. 


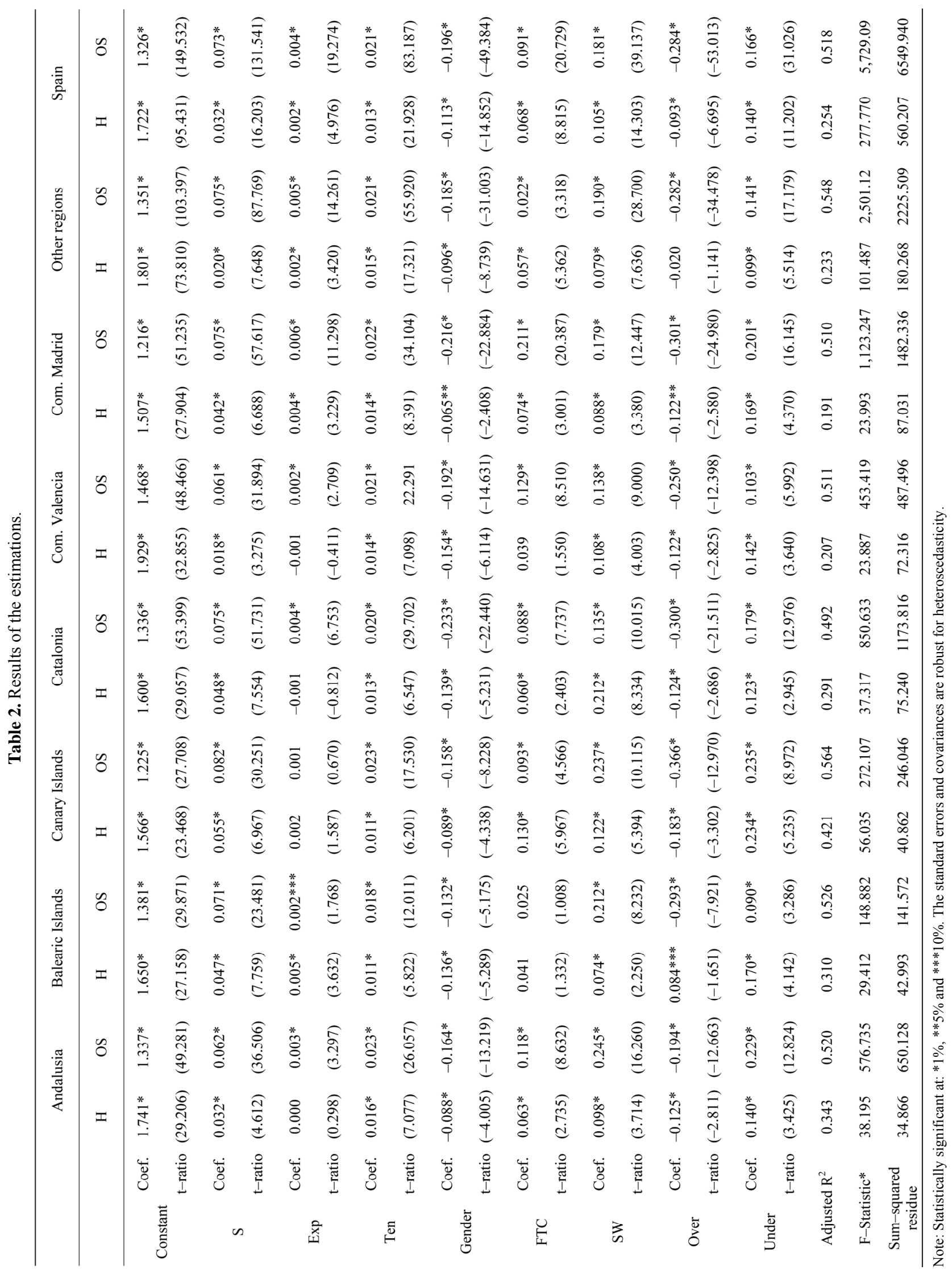


The returns estimated for previous experience and tenure in the firm are much lower than those for education. Once again, the estimations for the hospitality sector show returns to be quite lower than for the other private service sectors. Thus, Table 2 shows that the returns from previous experience are not statistically significant in the hospitality sector of four regions (Andalusia, the Canary Islands, Catalonia and Community of Valencia). On the other hand, the returns from tenure in the firm are statistically significant in all the regions, ranging from $1.1 \%$ (the Balearic and Canary Islands) to $1.6 \%$ (Andalusia).

In order to compare the potential effect of not includeing the square of the variables previous experience and tenure in the firm in our specification in order to avoid multicollinearity, Table A.1 presents estimations for Spain and the six aggregated regions ${ }^{6}$ which include these variables. As can be observed, not including these variables does not affect the coefficients estimated for the remaining explanatory variables. Furthermore, if returns are estimated using the sample mean of previous experience and tenure, the results obtained are very similar. In the case of Spain, in the expanded specification, the returns from previous experience and tenure are not statistically different from the ones presented in Table 2 .

The variable gender is statistically significant in all cases $^{7}$, and has a negative coefficient. Gender discrimination in the hospitality sector is greater in the Community of Valencia, where women have wages up to $13 \%$ lower than men. In the other service sectors, gender discrimination is greater in Catalonia, reaching $20.78 \%$. With the exception of the Balearic Islands, where wage differences due to gender are similar in the hospitality sector and other services in the private sector, the effect of gender on wages is less in the hospitality sector.

\subsubsection{Job Characteristics}

Except for the Balearic Islands (in all sectors) and the Community of Valencia (in the hospitality sector), where the estimated coefficient of the variable is not statisticcally different from zero, a full-time permanent contract involves increased wages. This increase ranges from $13.91 \%$ in the Canary Islands and $5.91 \%$ in the other regions.

The estimated coefficient for business size is statisticcally significant and positive in all cases. In the hospitality sector the wage premium of working in an establishment of 20 workers or more ranges from $23.66 \%$ in Catalonia to $7.65 \%$ in the Balearic Islands. Furthermore, except for Catalonia, wage improvements are greater in

\footnotetext{
${ }^{6}$ For the six regions, the sampling means of the variable previous experience is 14.03 years and tenure in the firm is 6.99 years.

${ }^{7}$ The impact on the wage of the dummy variables when using a semilog function was calculated by taking the antilogarithm of the corresponding coefficient, subtracting 1 and multiplying by 100 [19].
}

other service sectors than in the hospitality sector.

Finally, the estimated coefficients for educational mismatch have the expected signs in all cases and it is only statistically non significant in the aggregate of other regions (hospitality sector) for the overeducated workers. Overeducation involves a strong wage penalty which is greater in other service sectors than in the hospitality sector. On the other hand, undereducated workers earn between $26.40 \%$ more (in the hospitality sector in Catalonia) and $9.41 \%$ more (in other services in the Balearic Islands).

The results indicate great regional variability both in the hospitality sector and in the other private service sectors. Nevertheless, our estimations for Spain are not substantially different from those of [12] using a different database that included the public sector. These authors estimate the wage premium associated with undereducation at $13 \%$ and wage reductions for overeducated workers at $21 \%$.

\subsection{Decomposition of Regional Differences}

The mean wage in the Balearic Islands hospitality sector is higher than in the other tourist regions except for the Canary Islands. In fact it is $15.91 \%$ higher than the mean wage in the Community of Madrid, $9.35 \%$ higher than in Andalusia, $7.94 \%$ higher than in the Community of Valencia, and $5.84 \%$ higher than in Catalonia. However, there is a negative differential of $1.4 \%{ }^{8}$ compared to the Canary Islands. In this section, the wage difference between the Balearic Islands and the main Spanish tourism regions is decomposed following the methodology of [3]. Two different wage structures are assumed in the absence of discrimination. First, it is assumed that, in the absence of discrimination, the prevailing wage structure is that found in the Balearic Islands (model A). Then, a weighted mean of the wage structures for the six regions under analysis is used (model B). The aim is to obtain robust results given the non-discriminatory wage structure used as a reference. Based on the estimations of the wage equations in the hospitality sector for each region (shown in Table 2), the relative contributions of the observable variables on the total wage differential are created.

Tables 3 and Table A.2 show such contributions for models $\mathrm{A}$ and $\mathrm{B}$, respectively ${ }^{9}$, differentiating between the constant and personal and job characteristics. The results are robust given the non-discriminatory wage structure taken as reference. In each table, the first column in each region shows the portion of wage difference due to differences in observable characteristics; the sec-

\footnotetext{
${ }^{8}$ In all cases the reference is the real rate per hour worked in Euros.

${ }^{9}$ The results for model $\mathrm{B}$ are included in the Appendix because they are similar to model A, both in signs and relative contributions.
} 
Table 3. Relative effect on regional wage difference (A model).

\begin{tabular}{|c|c|c|c|c|c|c|c|c|c|c|c|c|c|c|c|}
\hline \multirow{2}{*}{ Factors } & \multicolumn{3}{|c|}{ Andalusia } & \multicolumn{3}{|c|}{ Canary Islands } & \multicolumn{3}{|c|}{ Catalonia } & \multicolumn{3}{|c|}{$\begin{array}{c}\text { Valencia } \\
\text { (Community of) }\end{array}$} & \multicolumn{3}{|c|}{$\begin{array}{c}\text { Madrid } \\
\text { (Community of) }\end{array}$} \\
\hline & Charact. & Returns & Total & Charact. & Returns & Total & Charact. & Returns & Total & Charact. & Returns & Total & Charact. & Returns & Total \\
\hline Constant & 0.00 & -195.89 & -195.89 & 0.00 & -185.88 & -185.88 & 0.00 & 198.71 & 198.71 & 0.00 & -428.03 & -428.03 & 0.00 & 111.83 & 111.83 \\
\hline $\begin{array}{c}\text { Personal } \\
\text { characteristics }\end{array}$ & 25.88 & 292.90 & 318.77 & -56.64 & 50.78 & -5.85 & -33.86 & 265.95 & 232.09 & 43.16 & 459.70 & 502.86 & 4.92 & -11.73 & -6.81 \\
\hline $\mathrm{S}$ & -75.42 & 241.68 & 166.26 & 0.00 & 122.70 & 122.70 & -220.26 & -22.49 & -242.75 & -37.71 & 333.14 & 295.43 & -33.70 & 28.43 & -5.28 \\
\hline Exp & 25.93 & 153.15 & 179.08 & 18.54 & -126.17 & -107.64 & 0.00 & 316.52 & 316.52 & 0.00 & 132.58 & 132.58 & 0.00 & 10.80 & 10.80 \\
\hline Ten & 75.37 & -47.68 & 27.69 & -75.18 & 2.61 & -72.56 & 143.91 & -34.86 & 109.05 & 62.26 & -21.18 & 41.08 & 20.32 & -15.00 & 5.32 \\
\hline Gender & 0.00 & -54.26 & -54.26 & 0.00 & 51.65 & 51.65 & 42.49 & 6.77 & 49.27 & 18.61 & 15.15 & 33.77 & 18.30 & -35.96 & -17.66 \\
\hline $\begin{array}{c}\text { Characteristics } \\
\text { of the job }\end{array}$ & 56.39 & -79.27 & -22.88 & 0.00 & 291.73 & 291.73 & 142.07 & -472.88 & -330.80 & 48.04 & -22.86 & 25.17 & 26.28 & -31.31 & -5.02 \\
\hline FTC & 0.00 & -68.09 & -68.09 & 0.00 & 188.16 & 188.16 & 0.00 & -116.81 & -116.81 & $\begin{array}{ll}1 \quad 0.00\end{array}$ & 0.00 & 0.00 & 0.00 & -29.76 & -29.76 \\
\hline SW & 0.00 & -42.48 & -42.48 & 0.00 & 84.31 & 84.31 & 0.00 & -416.56 & -416.56 & $\begin{array}{ll}6 & 0.00\end{array}$ & -39.68 & -39.68 & 0.00 & -8.41 & -8.41 \\
\hline Over & 9.61 & 17.76 & 27.38 & 0.00 & -27.08 & -27.08 & 17.30 & 32.24 & 49.55 & 2.34 & 9.88 & 12.22 & 4.93 & 6.69 & 11.62 \\
\hline Under & 46.78 & 13.54 & 60.31 & 0.00 & 46.34 & 46.34 & 124.77 & 28.25 & 153.02 & 45.70 & 6.94 & 52.63 & 21.36 & 0.17 & 21.53 \\
\hline Total & 82.27 & 17.73 & 100.00 & -56.64 & 156.64 & 100.00 & 108.21 & -8.21 & 100.00 & 91.20 & 8.80 & 100.00 & 31.21 & 68.79 & 100.00 \\
\hline
\end{tabular}

tion shows the wage difference due to differences in returns; and the last column shows the total relative contribution of each variable ${ }^{10}$. A positive value in a cell indicates that the variable under study increases the wage differential, whereas the opposite occurs when the sign is negative. However, the interpretation of the signs is just the reverse for the Canary Islands, as this is the only region that presents a favourable wage differential with regard to the Balearic Islands. Thus, for example, the difference in previous experience between these two regions contributes $18.54 \%$ to wage differences in model $\mathrm{A}$. Given that $\beta^{*}$ is positive ${ }^{11}$, and in the Balearic Islands for previous experience takes a mean value of 17.05 years (slightly less than in the Canary Islands [18.77 years]), this variable contributes an $18.54 \%$ decrease in the wage difference.

In model $\mathrm{A}$, the most of the wage gap in the Canary Islands and the Community of Madrid is due to differences in returns of the observable characteristics $(156.64 \%$ and $68.79 \%$, respectively), whereas in the other regions differences in resources are more relevant. Specifically, in Catalonia, this component contributes $108.29 \%$ to the

${ }^{10}$ If either the mean difference between the Balearic Islands and the region for a variable, or its estimated coefficient are not statistically different from zero at a $10 \%$ significance level, the relative impact is 0 . Similarly, if the coefficient estimated of a variable for the Balearic Islands is not significantly different from the estimate for the region under study, a zero is assigned to the contribution of the difference in returns of that variable.

${ }^{11}$ In the case of previous experience, $\beta^{*}=0.004864$ in model $\mathrm{A}$ and $\beta^{*}=$ 0.001231 in model B. wage gap, whereas in the Community of Valencia and Andalusia the contribution is $91.2 \%$ and $82.27 \%$, respecttively. Nevertheless, there are some differences. Although in both models most of the wage gap in Andalusia and the Community of Valencia is due to differences in observable characteristics, the relative contribution of differences in returns has a positive value in model A, whereas it is negative in model B. However, this is not especially relevant if we take into account that in both models the relative weight and the sign of the non-discriminatory and discriminatory effects are maintained in both personal and job characteristics. In order to simplify our description, from this point on we will only focus on the results from model A.

The contribution of the constant is significant for all the regions, which indicates that other factors different from the explanatory variables included in the estimations also have effects on wage differences. In the case of Andalusia and the Community of Valencia, the difference in returns for these external factors decrease the wage gap; however, the opposite occurs for the other regions, including the Canary Islands ${ }^{12}$.

Personal characteristics help to reduce wage differences only in the Community of Madrid, although their effect is not very relevant $(-6.81 \%)$. In the remaining cases, they contribute to increasing the wage gaps, espe-

\footnotetext{
${ }^{12}$ The reader should bear in mind that a negative sign in the cells of the Canary Islands implies an increase in the wage gap in the Balearic Islands when compared to this region.
} 
cially in the Community of Valencia, Andalusia and Catalonia (502.86\%, 318.77\% and $232.09 \%$, respectively). Such high contributions are basically due to the difference in returns. For example, the Community of Valencia and Andalusia present far lower returns from education and previous experience than the Balearic Islands, while low returns from previous experience is the leading cause in Catalonia. In the latter region, and in the Canary Islands, the higher returns of education help to reduce the wage differences by $22.4 \%$ and $122.70 \%$, respectively. All regions have returns from tenure in the firm higher than in the Balearic Islands, which helps to reduce the wage difference.

The fact of being woman has a negative contribution to wages in the hospitality sector in every region (Table 2). However, the difference in returns translates into different contributions to the wage gap. In the case of Andalusia, the Canary Islands, and the Community of Madrid, being a woman reduces the wage difference, whereas in Catalonia and the Community of Valencia it increases it. This is due to the fact that the returns of this variable in these two regions in absolute values are higher than in the Balearic Islands.

Regarding the differences in personal characteristics, tenure in the firm contributes to increase the wage gap in all regions, because the Balearic Islands have tenure values well above those found in the remaining destinations. This is probably due to the Balearic tourist model being well consolidated and the staff being stable. Exactly the opposite occurs regarding schooling years, because all the regions, except for the Canary Islands, have staffs with higher educational levels, which reduces the wage difference, especially in Catalonia and Andalusia (220.26\% and $75.42 \%$, respectively). The greater number of women in the hospitality sector in Catalonia and the Communities of Valencia and Madrid increases the wage gap due to gender wage discrimination. Finally, differences in previous experience contribute nothing in Catalonia and the Communities of Valencia and Madrid.

The Canary Islands present some peculiarities. The insular nature of both the Balearic and Canary Islands means that no statistically significant differences are found in the characteristics of workers and jobs. In fact, the wage gap is only affected by differences in previous experience and tenure in the firm, whereas the differences in other variables make no contribution. As the previous example indicates, greater previous experience in the Canary Islands causes an $18.54 \%$ reduction in the wage gap, whereas less tenure contributes to increasing the wage difference by around $75.18 \%$.

Significant differences in most job characteristics are shown, except for the size of the business, because this variable does not affect wage difference in any region.
Therefore, the unequal distribution of establishments between regions regarding mean size does not seem to have an effect on wage difference ${ }^{13}$. Except for the Canary Islands, the number of workers who are overeducated for their job is greater in all regions than in the Balearic Islands. This fact contributes to increasing the wage gap, since overeducation has a negative effect on wages. This also occurs with workers who are undereducated for their jobs, although in this case the relative contribution is greater for all the regions. The higher relative weight is due to the fact that returns from undereducation is positive, and that the Balearic Islands have the highest percentage of undereducation.

Regarding the difference in returns from job characteristics, the type of contract and firm size make a negative contribution to the wage gap. The difference in return from the type of contract makes the greatest contribution to reducing wage differences in all the regions, except for the Community of Valencia. In this regard, the contribution of the variable type of contract is $188.16 \%$ and $116.81 \%$ in the Canary Islands and Catalonia, respectively. Finally, the difference in returns from firm size contributes to reducing the wage gap in all cases, and is especially relevant in Catalonia and the Canary Islands (416.56\% and $84.31 \%$, respectively). In the case of Catalonia, the wage increase an individual receives when changing from working in a small establishment to one with more than 20 employees is almost triple the returns a worker with similar characteristics would obtain in the Balearic Islands (as shown in Table 2). In other words, large establishments pay more in Catalonia than in the Balearic Islands.

\section{Conclusions}

This article provides new empirical evidence on human capital returns and regional wage differences in the Spanish hospitality sector. The use of establishment-worker paired data allows us to analyze regional disparities in this context. This analysis focuses on the main tourist regions in Spain. The differential behaviour of the labour market and the significant structural differences that exist between regions drives the need to study each region individually. Similarly, the regions analyzed present marked differences concerning the tourism segment they have specialized in. The Community of Madrid is characterised by being a cultural destination and the Capital of Spain, whereas Valencia, Andalusia and Catalonia are

\footnotetext{
${ }^{13}$ As described in section 2, ideally the variables size of the establishment and type of activity should have been included, making a distinction between hotels and restaurants. Including these variables would make it possible to analyze the impact of the type of activity and business size, respectively, on wage differences. In this way, we could have estimated how the differences in the mean size of hotels in different regions affect wage differences.
} 
coastal destinations specialized in the sun and beach segments with some cultural tourism and the Canary Islands and the Balearic Islands are highly specialized insular destinations with consolidated sun and beach tourism.

The estimations obtained for the different regions enable us to quantify the returns of human capital variables, such as schooling years, previous experience and tenure in the firm, as well as to compare their value to those obtained from other private services. In all the regions, returns from education are less in the hospitality sector than in the other private service sectors. Although the returns from education are less than those reported in other studies, they are compatible with them, since we introduced additional control variables related to the job characteristics that reduce returns ${ }^{14}$. Similarly, the estimated returns for previous experience and tenure in the firm are less in the hospitality sector than in other sectors, being in turn lower than those of the education.

Gender wage differences are found in all the regions. In general, this problem is more significant in the hospitality sector than other private services. These results reveal a situation that can be generalised to most countries, i.e., the hospitality sector is characterized by lower pay to workers with similar characteristics, and women are especially penalised in this regard. The lower wages women receive may be strongly affected by the greater segregation they experience, as women are mainly found in the worst-paid industries, establishments, jobs, functional areas and responsibility levels. The works of [22], [23], [24] or [25] reveal the importance of different types of segregation on the gender wage gap in the hospitality sector.

Regarding the job characteristics, there is a positive wage premium associated with stability in the type of contracts and establishment size. These results are compatible with other studies, as they point out that mean wages increase in a large company as the number of employees with a contract based on union agreements increases. This could be due to the negotiation system in Spain, where specific worker agreements with the firm are used to improve the labour conditions agreed at regional levels [26]. Finally, the effects of the mismatch between educational level and job requirements are compatible with estimates reported in the literature. In particular, overeducation has a negative effect on wages in the hospitality sector, whereas undereducation has a positive effect.

The breakdown of the wage gap between the Balearic Islands and each region serves to quantify the part of this

\footnotetext{
${ }^{14}$ See for example, [20], [3] or [2]. Nevertheless, the latter author includes additional personal characteristics, such as marital status and number of children, and other characteristics related to human capital, using dummy variables associated with the highest educational level achieved by the worker.
}

differential attributable to differences in productivity from the part due to differences in returns of the observable characteristics. This is highly relevant from the standpoint of the disparities between regional characteristics, and has potential implications regarding labour mobility between regions. The Balearic Islands was chosen as the reference region because of the high relevance of employment in this sector in relative terms, and the high number of hotel bed places and large establishments. The results obtained are robust given the non-discriminatory wage structure considered. The evidence helps to draw conclusions that have relevant implications for economic policies.

Wage gap decomposition in the hospitality sector shows that, overall, wage discrimination is significant in all Spanish regions, given that workers who work in identical conditions and who have identical characteristics have different wages depending on the region where they are employed. However, this is especially relevant in the Canary Islands and the Community of Madrid. In these two cases, most wages differences are accounted for differences in the returns on characteristics, which mean these two regions show higher distortions or failures in the labour market. Wage discrimination is basically driven by differences in returns on personal characteristics in Catalonia, Andalusia and the Community of Valencia. In these last two cases, the increased wage gap is basically due to lower returns from education. Returns from the job characteristics also have an influence, but in the opposite direction, as they help to reduce wage differences compared to the Balearic Islands. This effect is stronger in the case of Catalonia and Canary Islands.

Finally, it is worth noting that there are variables not included in the wage equation specification that can be determinants of regional differences, such as the regional unemployment rate or to what extent the tourism development model has been consolidated, among others. In this regard, it is of interest to note that those regions more specialized in the hospitality sector, such as the Balearic Islands and the Canary Islands, present an employment pattern that is far from the stereotype in this sector regarding precariousness and low returns from education. This analysis may indicate that the level of tourism development in a region could encourage greater stability regarding contracts and better wages as the educational status of the workers increases.

\section{REFERENCES}

[1] Instituto Nacional de Estadística (INE), Encuesta de Estructura Salarial 2006 (Microdatos), Madrid: INE, 2007.

[2] M. Fernández and Y. Pena-Boquete, "Condiciones de Trabajo y Empleo en la Hostelería en España: Existe un Modelo Nacional?" XVI Jornadas de la Asociación de 
Economía de la Educación, Palma de Gran Canaria, 2007.

[3] R. Oaxaca and M. R. Ransom, "On Discrimination and the Decomposition of Wage Differentials," Journal of Econometrics, No. 61, 1994, pp. 5-21. doi:10.1016/0304-4076(94)90074-4

[4] R. Oaxaca, "Male-Female Wage Differentials in Urban Labor Markets," International Economic Review, Vol. 14, No. 3, 1973, pp. 693-709. doi: $10.2307 / 2525981$

[5] A. Blinder, "Wage Discrimination: Reduced Form and Structural Estimates," Journal of Human Resources, No. 8, 1973, pp. 436-455. doi:10.2307/144855

[6] L. Serrano, "Salarios Regionales y Dotaciones de Capital Humano," Revista de Economía Aplicada, Vol. 28, No. 1, 2002, pp. 23-38.

[7] J. Cotton "On the Decomposition of Wage Differentials," Review of Economics and Statistics, No. 70, 1988, pp. 236-243. doi:10.2307/1928307

[8] M. Arrazola, J. Hevia, M. Risueño and J. F. Sanz, "Returns to Education in Spain: Some Evidence on the Endogeneity of Schooling," Education Economics, Vol. 11, No. 3, 2003, pp. 293-304. doi:10.1080/0964529032000148818

[9] J. Alcaide and P. Alcaide, "Avance de las Magnitudes Económicas Españolas en 2008 y Serie Provisional del Balance Económico Regional. Años 2000 a 2008," Cuadernos de Información Económica, No. 208, 2009, pp. $1-65$.

[10] Instituto de Estudios Turísticos (IET), El turismo español en cifras, Madrid: IET, 2007.

[11] C. M. Schmidt and K. F. Zimmermann, "Work Characteristics, Firm Size and Wages," The Review of Economics and Statistics, Vol. 73, No. 4, 1991, pp. 705-710. doi: $10.2307 / 2109410$

[12] H. Strauss and C. Maisonneuve, "The Wage Premium on Tertiary Education: New Estimates for 21 OECD Countries," OECD Economics Department Working Papers, OECD Publishing, No. 589, 2007.

[13] Instituto Nacional de Estadística (INE), Clasificación Nacional de Ocupaciones, Madrid: INE, 1994.

[14] A. E. Aguiló and J. Alegre, "La Madurez de los Destinos Turísticos de Sol y Playa," Papeles de Economía Española, No. 102, 2004, pp. 250-270.

[15] A. J. Marchante, B. Ortega and R. Pagán, “Educational
Mismatch and Wages in the Hospitality Sector," Tourism Economics, Vol. 11, No. 1, 2005, pp. 103-117. doi: $10.5367 / 0000000053297149$

[16] D. Nickson, "Human Resource Management for the Hospitality and Tourism Industries," Oxford, UK: Butterworth-Heinemann, 2007.

[17] J. M. Pastor, J. L. Raymond, J. L. Roig and L. Serrano, "El Rendimiento del Capital Humano en España," Valencia: IVIE, 2006.

[18] A. Lillo-Bañuls and J. M. Casado-Díaz, "Rewards to Education in the Tourism Sector: One Step Ahead," Tourism Economics, Vol. 16, No. 1, 2010, pp. 11-23. doi: $10.5367 / 000000010790872033$

[19] R. Halvorsen and R. Palmquist, "The Interpretation of Dummy Variables in Semilogarithmic Equations," American Economic Review, Vol. 70, No. 3, 1980, pp. 474 475.

[20] A. Lillo-Bañuls and A. B. Ramón-Rodríguez, "Returns to Education in the Spanish Tourism Labour Market," Tourism Economics, Vol. 11, No. 1, 2005, pp. 119-132. doi: $10.5367 / 0000000053297176$

[21] C. Thrane, "Earnings Differentiation in the Tourism Industry: Gender, Human Capital and Socio-Demographic Effects," Tourism Management, Vol. 29, No. 3, 2008, pp. 514-524. doi:10.1016/j.tourman.2007.05.017

[22] C. W. Ng and R. Pine, "Women and Men in Hotel Management in Hong Kong: Perceptions of Gender and Career Development Issues," International Journal of Hospitality Management, No. 22, 2003, pp. 85-102.

[23] L. D. Delfim and J. Varejao, "Employment, Pay and Discrimination in the Tourism Industry," Tourism Economics, Vol. 13, No. 2, 2007, pp. 225-240. doi: $10.5367 / 000000007780823186$

[24] O. Skalpe, "The CEO Gender Pay Gap in Tourism Industry: Evidence from Norway," Tourism Management, No. 28, 2007, pp. 845-853. doi:10.1016/j.tourman.2006.06.005

[25] J. A. Campos-Soria, B. Ortega and M. A. Ropero-García, "Gender Segregation and Wage Difference in the Hospitality Industry," Tourism Economics, Vol. 15, No. 4, 2009, pp. 847-866. doi: $10.5367 / 000000009789955152$

[26] R. Aláez, J. C. Longás and M. Ullibarri, "Diferencias Salariales en España: Un Análisis Sectorial/Regional," Investigaciones Regionales, No. 3, 2003, pp. 5-24. 


\section{Appendix}

Table A.1. Results of the estimations for Spain (expanded model) and some chosen regions (expanded and basic models) in the hospitality sector.

\begin{tabular}{|c|c|c|c|c|}
\hline \multirow{2}{*}{ Factor } & & \multicolumn{2}{|c|}{ Expanded model } & Basic model \\
\hline & & Spain. & 6 regions & 6 regions \\
\hline \multirow{2}{*}{ Constant } & Coefficient & $1.701^{*}$ & $1.641^{*}$ & $1.671^{*}$ \\
\hline & t-ratio & $(78.707)$ & $(56.190)$ & $(67.414)$ \\
\hline \multirow{2}{*}{ S } & Coefficient & $0.032 *$ & $0.040^{*}$ & $0.039^{*}$ \\
\hline & t-ratio & (16.172) & (14.717) & (14.653) \\
\hline \multirow{2}{*}{ Exp } & Coefficient & $0.005^{*}$ & $0.006^{*}$ & 0.002 \\
\hline & t-ratio & $(3.373)$ & $(3.260)$ & (3.394) \\
\hline \multirow{2}{*}{ Exp_Squared } & Coefficient & $-0.000^{* *}$ & $-0.000 * *$ & - \\
\hline & t-ratio & $(-2.038)$ & $(-2.439)$ & - \\
\hline \multirow{2}{*}{ Ten } & Coefficient & $0.014 *$ & $0.010^{*}$ & $0.012 *$ \\
\hline & t-ratio & $(8.087)$ & (4.433) & $(15.545)$ \\
\hline \multirow{2}{*}{ Ten_Squared } & Coefficient & -0.000 & 0.000 & - \\
\hline & t-ratio & $(-0.342)$ & $(0.979)$ & - \\
\hline \multirow{2}{*}{ Gender } & Coefficient & $-0.113^{*}$ & $-0.124^{*}$ & $-0.124^{*}$ \\
\hline & t-ratio & $(-14.895)$ & $(-11.979)$ & $(-12.032)$ \\
\hline \multirow{2}{*}{ FTC } & Coefficient & $0.065^{*}$ & $0.077^{*}$ & $0.076^{*}$ \\
\hline & t-ratio & $(8.228)$ & $(6.930)$ & (7.134) \\
\hline \multirow{2}{*}{ SW } & Coefficient & $0.105^{*}$ & $0.125^{*}$ & $0.125^{*}$ \\
\hline & t-ratio & $(14.296)$ & $(11.227)$ & (11.246) \\
\hline \multirow{2}{*}{ Over } & Coefficient & $-0.092 *$ & $-0.136^{*}$ & $-0.137 *$ \\
\hline & t-ratio & $(-6.664)$ & $(-6.963)$ & $(-6.973)$ \\
\hline \multirow{2}{*}{ Under } & Coefficient & $0.140^{*}$ & $0.163^{*}$ & $0.163^{*}$ \\
\hline & t-ratio & $(11.218)$ & (9.989) & $(9.970)$ \\
\hline \multicolumn{2}{|c|}{ Adjusted $\mathrm{R}^{2}$} & 0.254 & 0.265 & 0.264 \\
\hline \multicolumn{2}{|c|}{ F-Statistic } & $222.891^{*}$ & $140.807 *$ & $175.063^{*}$ \\
\hline \multicolumn{2}{|c|}{ Sum-squared residue } & 559.731 & 373.095 & 373.682 \\
\hline \multicolumn{2}{|c|}{ Obs. } & 6515 & 3874 & 3874 \\
\hline
\end{tabular}

Significant at: $* 1 \%$. $* 5 \%$ and $* * * 10 \%$. The standard errors and covariances are robust for heteroscedasticity.

Table A.2. Relative effect on regional wage difference (B model).

\begin{tabular}{|c|c|c|c|c|c|c|c|c|c|c|c|c|c|c|c|}
\hline \multirow{2}{*}{ Factors } & \multicolumn{3}{|c|}{ Andalusia } & \multicolumn{3}{|c|}{ Canary Islands } & \multicolumn{3}{|c|}{ Catalonia } & \multicolumn{3}{|c|}{ Valencia (Community of) } & \multicolumn{3}{|c|}{ Madrid (Community of) } \\
\hline & Charact. & Returns & Total & Charact. & Returns & Total & Charact. & Returns & Total & Charact. & Returns & Total & Charact. & Returns & Total \\
\hline Constant & 0.00 & -187.59 & -187.59 & 0.00 & -200.81 & -200.81 & 0.00 & 194.92 & 194.92 & 0.00 & -461.05 & -461.05 & 0.00 & 113.01 & 113.01 \\
\hline $\begin{array}{c}\text { Personal } \\
\text { characteristics }\end{array}$ & 36.01 & 271.84 & 307.86 & -95.47 & 85.64 & -9.83 & 25.22 & 211.13 & 236.35 & 65.26 & 472.47 & 537.74 & 11.44 & -18.57 & -7.13 \\
\hline $\mathrm{S}$ & -61.81 & 221.02 & 159.21 & 0.00 & 130.11 & 130.11 & -184.92 & -53.20 & -238.12 & -34.77 & 352.99 & 318.22 & -29.15 & 23.81 & -5.33 \\
\hline Exp & 7.56 & 163.92 & 171.48 & 6.10 & -122.39 & -116.29 & 0.00 & 319.17 & 319.17 & 0.00 & 138.89 & 138.89 & 0.00 & 10.67 & 10.67 \\
\hline Ten & 90.26 & -63.74 & 26.52 & -101.57 & 23.18 & -78.40 & 176.54 & -69.57 & 106.97 & 83.87 & -39.62 & 44.25 & 25.68 & -20.31 & 5.38 \\
\hline Gender & 0.00 & -49.36 & -49.36 & 0.00 & 54.75 & 54.75 & 33.59 & 14.73 & 48.33 & 16.16 & 20.21 & 36.37 & 14.91 & -32.75 & -17.84 \\
\hline $\begin{array}{c}\text { Characteristics } \\
\text { of the job }\end{array}$ & 71.19 & -91.46 & -20.27 & 0.00 & 310.64 & 310.64 & 170.46 & -501.73 & -331.27 & 63.76 & -40.44 & 23.31 & 32.68 & -38.55 & -5.88 \\
\hline FTC & 16.36 & -81.57 & -65.20 & 0.00 & 201.29 & 201.29 & 33.00 & -147.58 & -114.58 & 14.97 & -14.97 & 0.00 & 5.44 & -35.51 & -30.07 \\
\hline SW & 0.00 & -39.04 & -39.04 & 0.00 & 91.47 & 91.47 & 0.00 & -415.39 & -415.39 & 0.00 & -46.55 & -46.55 & 0.00 & -9.30 & -9.30 \\
\hline Over & 13.90 & 12.32 & 26.22 & 0.00 & -31.78 & -31.78 & 25.63 & 22.98 & 48.60 & 3.81 & 9.36 & 13.17 & 7.52 & 4.23 & 11.74 \\
\hline Total & 107.21 & -7.21 & 100.00 & -95.47 & 195.47 & 100.00 & 195.68 & -95.68 & 100.00 & 129.02 & -29.02 & 100.00 & 44.12 & 55.88 & 100.00 \\
\hline
\end{tabular}

The weighted mean for the 6 regions is assumed as a non-discriminatory wage structure $\left(\beta^{*}=\sum_{n=1}^{6} \Omega_{n} \hat{\beta}_{n}\right)$. 